\title{
Patterns of Nutrient Dynamics within and below the Rootzone of Collard Greens Grown under Different Organic Amendment Types and Rates
}

\author{
Ripendra Awal 1,*(D), Almoutaz El Hassan ${ }^{1}$, Farhat Abbas ${ }^{2} \mathbb{D}$, Ali Fares ${ }^{1}\left(\mathbb{D}\right.$, Haimanote K. Bayabil $^{3} \mathbb{D}$, \\ Ram L. Ray ${ }^{1}$ (D) and Selamawit Woldesenbet ${ }^{1}$ \\ 1 College of Agriculture and Human Sciences, Prairie View A\&M University, Prairie View, TX 77446, USA; \\ aaelhassan@pvamu.edu (A.E.H.); alfares@pvamu.edu (A.F.); raray@pvamu.edu (R.L.R.); \\ sewoldesenbet@pvamu.edu (S.W.) \\ 2 School of Climate Change and Adaptation, University of Prince Edward Island, \\ Charlottetown, PE C1A 4P3, Canada; fabbas@upei.ca \\ 3 Agricultural and Biological Engineering, Tropical Research and Education Center, Institute of Food and \\ Agricultural Sciences, University of Florida, Homestead, FL 33031, USA; hbayabil@ufl.edu \\ * Correspondence: riawal@pvamu.edu; Tel.: +1-936-261-5092
}

\section{check for} updates

Citation: Awal, R.; Hassan, A.E.; Abbas, F.; Fares, A.; Bayabil, H.K.; Ray, R.L.; Woldesenbet, S. Patterns of Nutrient Dynamics within and below the Rootzone of Collard Greens Grown under Different Organic Amendment Types and Rates. Sustainability 2021, 13, 6857. https:// doi.org/10.3390/su13126857

Academic Editors: Oldřich Látal, Petr Šařec and Petr Novák

Received: 26 April 2021

Accepted: 14 June 2021

Published: 17 June 2021

Publisher's Note: MDPI stays neutral with regard to jurisdictional claims in published maps and institutional affiliations.

Copyright: (c) 2021 by the authors. Licensee MDPI, Basel, Switzerland. This article is an open access article distributed under the terms and conditions of the Creative Commons Attribution (CC BY) license (https:/ / creativecommons.org/licenses/by/ $4.0 /)$.

\begin{abstract}
The knowledge about nutrient dynamics in the soil is pivotal for sustainable agriculture. A comprehensive research trial can retort unanswered questions. Dynamics of nutrients sourced from organic amendment types (chicken manure, dairy manure, and Milorganite ${ }^{\mathrm{TM}}$ ) applied at different rates $(0,168,336,672 \mathrm{~kg}$ total $\mathrm{N} / \mathrm{ha})$ were monitored within and below the rootzone of collard greens cultivated on a sandy loam soil in Prairie View, TX, USA. Macro- and micronutrients (e.g., TN: total nitrogen, P: phosphorous, K: potassium, Na: sodium, Ca: calcium, Mg: magnesium, B: boron, $\mathrm{Cu}$ : copper, Fe: iron, and $\mathrm{Zn}$ : zinc) were analyzed from soil solution samples collected during six sampling periods from within and below the rootzone. As hypothesized, the organic amendment types and rates significantly ( $p<0.05$ and/or 0.01 ) affected nutrient dynamics within and below the crop rootzone. Chicken manure released significantly more $\mathrm{TN}, \mathrm{P}, \mathrm{K}, \mathrm{Na}, \mathrm{Ca}, \mathrm{Mg}$, B, Cu, and Fe than the other two amendments. The application of chicken manure and Milorganite ${ }^{\mathrm{TM}}$ resulted in higher below-the-rootzone leachate concentration of $\mathrm{TN}, \mathrm{Na}, \mathrm{Mg}$, and $\mathrm{Ca}$ than in the leachates of dairy manure. Dairy manure treatments had the lowest concentrations of TN, Ca, and $\mathrm{Mg}$; whereas, Milorganite $^{\mathrm{TM}}$ had the lowest concentrations of $\mathrm{P}, \mathrm{K}, \mathrm{Na}, \mathrm{B}$, and $\mathrm{Cu}$ in the collected leachates. The higher level of $\mathrm{P}$ (i.e., $4 \%$ in Milorganite ${ }^{\mathrm{TM}}$ as compared to 2 and $0.5 \%$ in chicken and dairy manures, respectively, might have reduced the formation of Vesicular-Arbuscular (VA) mycorrhizae-a fungus with the ability to dissolve the soil $\mathrm{P}$, resulting in slow release of $\mathrm{P}$ from Milorganite ${ }^{\mathrm{TM}}$ treatment than from the other two treatments. Patterns of nutrient dynamics varied with rain and irrigation events under the effects of the soil water and time lapse of the amendment applications' rates and types. All the macronutrients were present within the rootzone and leached below the rootzone, except Na. The dynamic of nutrients was element-specific and was influenced by the amendments' type and application rate.
\end{abstract}

Keywords: agricultural production; environmental safety; organic amendments; nutrient dynamics; soil fertility

\section{Introduction}

Collard greens (Brassica oleracea var. acephala) are among the vegetables that make a favorite dish at restaurants and attractive isles in food sections of major stores across the southern USA, South America, and China. People prefer it as a part of healthy diets, usually comprising fibrous leafy vegetables rich in vitamins and low in calories [1,2]. There are intense demands for fresh and processed collard greens. 
Production of collard greens requires nutrient-rich soil. Efficient nutrient management is essential for optimum crop yield; it accounts for nutrient dynamics below crops' rootzone. A lack of awareness of the dangers in-built in the mere use of fertilizer alone for enhancing crop productivity deteriorates soil health and the environment [3]. For healthy soils and a clean environment, the use of synthetic fertilizers can be reduced by using organic sources of plant nutrients without compromising crop production [4].

Applying fertilizers to soils enhances their health and provides crops with nutrients needed for their development and growth [5]. Organic agriculture uses organic manures as the only source of plant nutrients. Poultry manure is a rich source of major macronutrients [6]. It also contains high concentrations of micronutrients, including $\mathrm{Cu}$ and $\mathrm{Zn}$ [7], apparently derived from growth promoters in poultry feed [8]. Dairy manure, poultry manure, and Milorganite (a biosolid) are sources of necessary crop macro- and micronutrients [9-12]. Cattle manure is a good source of nutrients, such as $\mathrm{N}, \mathrm{P}, \mathrm{K}, \mathrm{S}$, and $\mathrm{Mg}$, coming from livestock diets and other trace elements. Reported values of nutrients found in cattle manure include $7.89 \mathrm{~g} \mathrm{~kg}^{-1}$ for $\mathrm{P}, 38.45 \mathrm{~g} \mathrm{~kg}^{-1}$ for $\mathrm{K} \mathrm{[13],} \mathrm{and} \mathrm{2-8.1} \mathrm{g} \mathrm{kg}^{-1}$ for $\mathrm{N}$ [14].

Milorganite $^{\mathrm{TM}}$ (MILwaukee ORGAnic NITtrogEn), introduced by the Milwaukee Metropolitan Sewerage District (Milwaukee, WI), is a Class A biosolid [15] that meets the US EPA standards for arsenic, cadmium, $\mathrm{Cu}$, lead, mercury, molybdenum, nickel, selenium, and $\mathrm{Zn}$ limits [16]. Having an N-P-K ratio of 6-2-0 and low solubility compared to commercial fertilizers, Milorganite ${ }^{\mathrm{TM}}$ is distributed without restriction and labeling their origin or pollutant content [17]. It has been reported to be significantly more phytoavailable than triple superphosphate (TSP) in Candler Florida soil [18] and for its property of least cumulative P release than biological P removal (BPR) and other BPR-like biosolids [19].

The mobility of nutrients in the vadose zone is a function of the rate and time of application of manure and/or biosolids applications. Excessive application of chicken manure $(\mathrm{CM})$ can result in nitrate $\left(\mathrm{NO}_{3}-\mathrm{N}\right)$ abundance in the crop rootzone. Once leached below the rootzone, $\mathrm{NO}_{3}-\mathrm{N}$ is beyond plant uptake and eventually ends up in groundwater aquifers [20]. Phosphorous is readily available for plant uptake in most soils. Most of the added $\mathrm{P}$ tends to be attracted to soil particle charges resulting in its minimum leaching down the soil profile.

Furthermore, $\mathrm{P}$ is cycled from roots to aboveground parts of the plant and is redeposited in crop residues on the soil surface. Therefore, most agricultural fields need lower quantities of $\mathrm{P}$ than $\mathrm{N}$ that may be supplied with slow-releasing soil amendments. Applying manure or biosolids to meet plant $\mathrm{N}$ requirements often results in the excessive application of P [16]. Excessive P accumulation is not harmful to crops but could lead to several environmental problems, especially in poor P-sorbing soils [19]. Once applied to agricultural fields, $\mathrm{P}$ has a tendency of attachment with soil particles [21]. Potassium, as a macronutrient, is a fundamental element for plant growth, which markedly affects biomass accumulation and biomass partitioning [22]. Showing an elusive behavior, K exchange in heterogeneous systems has been reported to be in equilibrium rather than a dynamic nature [23]. Other macro- and micronutrients have been reported to have miscellaneous trends in their dynamics depending upon their source of origin and the type of soils they were considered in $[16,24,25]$ resulting in good crop growth but at some times soil and environmental degradations.

Organic agriculture supports environmental stewardship. Commercial-scale recycling of agricultural and municipal wastes into organic soil amendments facilitates safe disposal of waste, improves soil health, and reduces environmental degradation [26]. Tanha [27] conducted a field experiment to examine the changes in pedostructure-based soil characterization under different soil management methods involving three organic treatments (chicken, dairy manure, and Milorganite) applied at three different rates and found that the dairy manure had improved soil aggregate structure better than chicken manure and Milorganite. Organic amendment types and rates influence the rhizosphere and phyllosphere microbiota profiles of collard greens [28]. Kebrom et al. [29] evaluated phytotoxicity of chicken manure, Milorganite, and dairy manure to collard greens and 
identified phytotoxic effects of chicken manure and Milorganite, but not dairy manure, to collard greens. Particularly, nickel in chicken manure and Milorganite aqueous extracts was 28-fold and 21-fold, respectively, higher than previously reported toxic levels to wheat seedlings. Kebrom et al. [26] identified phytotoxic levels of copper and nickel in commercial organic soil amendments recycled from poultry farms and municipal wastes and found that commercial chicken manure and Milorganite (recycled from municipal waste) were more phytotoxic than poultry manure. Application of exogenous $\mathrm{N}$ fertilizers (poultry or chicken manure and/or biosolids such as Milorganite) provides agronomic benefits but carries environmental liabilities [30]. For example, higher cumulative $\mathrm{CO}_{2}$ emissions for the soils amended with chicken manure and Milorganite but the lowest for the soils amended with dairy manure were reported by Ray et al. [31]. Organic agriculture faces challenges of balancing the use of organic manures either in the form of dry manure or in the shape of manure slurry to fulfill crop nutrient requirements on efficient basis.

Application of exogenous organic matter, sourced from natural fertilizers including dry organic manures and/or slurry, to soil enriches it with micro- and macro-elements necessary for the growth and yield of crops [32]. However, managing benefits and liabilities of $\mathrm{N}$-based fertilizers in conventional and organic cropping systems (managed by the application of only organic manures or organic manures mixed with synthetic fertilizers) might be improved with better knowledge of nutrient dynamics, the generation of intrinsic $\mathrm{N}$, and maintenance of soil organic matter [31]. The knowledge about nutrient dynamics in the soil is pivotal for sustainable agriculture and a safe environment.

Effective nutrient management can address issues of sustainable agriculture and environmental stewardship as water, soil, and nutrient management are highly interconnected [33]. Thus, the best agricultural management practices help developing solutions to the broader challenges that restrict farm profitability [34]. Effective nutrient management facilitates farmer learning about nutrient dynamics within and below rootzone as well as augments the learning from the soil and nutrient monitoring [35]. Innovative agricultural management practices have been discussed in detail elsewhere [36,37]. Good agricultural management practices include practices to manage soil, water, and nutrients for ideal soil health and productivity.

Organic soil amendments provide crops with their nutrient needs and maintain soil health by modifying their physical, chemical, and biological properties [29,38]. Small-scale vegetable and fruit crop growers are transitioning from conventional farming to environmentally friendly and more profitable semi-organic or organic farming [39]; therefore, they are shifting from using conventional inorganic fertilizers to organic fertilizers and soil amendments prepared from municipal, industrial, and farm wastes [40]. Agronomic management through better use of inputs benefits farmers both by enhancing productivity and profitability [41].

An extensive literature review did not reveal any detailed study on the effect of organic amendment types and rates on dynamics of macro- and micronutrients within and below the rootzone of collard greens under southeast Texas edaphic conditions. It was hypothesized the dynamics of macro- and micronutrients within and below the crop rootzone would vary with organic amendment types and rates. There is a need to quantify the effects of different organic amendment types and application rates on nutrient availability and fate within and below the rootzone during such conditions. Therefore, this study's objective was to quantify the effect of organic amendment types and rates on dynamics of macro- and micronutrients within and below the rootzone of collard greens under southeast Texas edaphic conditions.

\section{Materials and Methods}

\subsection{Experimental Field}

This experiment was conducted at the University Research Farm of the College of Agriculture and Human Sciences, Prairie View A\&M University, Prairie View, Texas, USA. This area's annual rainfall varies from 460 to $1914 \mathrm{~mm}$, with an average annual 
rainfall of $1126 \mathrm{~mm}$ based on monthly rainfall data from 1980 to 2018 (PRISM data: http:/ /www.prism.oregonstate.edu/, accessed on 12 January 2020). The soil at the field is classified as Wockley fine sandy loam. The taxonomic class of the Wockley Series based on US Soil Taxonomy is fine-loamy, siliceous, semiactive, hyperthermic Plinthaquic Paleudalfs. Selected characteristics of this soil are shown in Table 1.

Table 1. Selected characteristics of Wockley fine sandy loam soil at the experimental field.

\begin{tabular}{|c|c|c|c|c|c|c|}
\hline \multirow{2}{*}{$\begin{array}{l}\text { Depth } \\
\text { (cm) }\end{array}$} & \multirow{2}{*}{$\begin{array}{c}\text { Soil Horizon and } \\
\text { Texture }\end{array}$} & \multicolumn{3}{|c|}{$\%$} & \multirow{2}{*}{$\begin{array}{c}\text { Ksat } \\
(\mathrm{cm} / \mathrm{hr})\end{array}$} & \multirow{2}{*}{$\mathrm{pH}$} \\
\hline & & Sand & Silt & Clay & & \\
\hline $0-18$ & A-Fine sandy loam & $61-70$ & $26-32$ & $4.0-7.0$ & \multirow{4}{*}{0.97} & $5.1-6.0$ \\
\hline $18-56$ & E-Fine sandy loam & $51-62$ & $29-40$ & $6.0-9.0$ & & $5.6-6.5$ \\
\hline $56-147$ & Btc-Sandy clay loam & $45-52$ & $17-31$ & $22-37$ & & $5.1-6.5$ \\
\hline 147-203 & Btcv-Sandy clay loam & $38-46$ & $19-23$ & $31-46$ & & $5.6-6.5$ \\
\hline
\end{tabular}

\subsection{Organic Amendments, Experimental Design, and Agronomic Practices}

Four application rates of chicken manure, dairy manure, and Milorganite ${ }^{\mathrm{TM}}$ biosolid were applied on 36 raised bed plots $(300 \mathrm{~cm} \times 150 \mathrm{~cm})$. The application rates were based on the recommended nitrogen rate per hectare (N/ha). They included: (i) 0 (no-amendment control), (ii) 168 (low $\mathrm{N}$ rate), (iii) 336 (medium $\mathrm{N}$ rate), and $672 \mathrm{~kg}$ total N/ha (high $\mathrm{N}$ rate). The chemical properties of organic amendments are summarized in Table 2.

Table 2. Properties of organic amendments showing the composition of nutrients, $\mathrm{pH}$, and electrical conductivity.

\begin{tabular}{|c|c|c|c|c|c|c|c|c|c|c|c|c|c|c|c|c|c|}
\hline \multirow[b]{2}{*}{$\mathrm{OA}^{*}$} & \multicolumn{3}{|c|}{$\%$} & \multicolumn{14}{|c|}{ ppm } \\
\hline & $\mathbf{N}$ & $\mathbf{P}$ & $\mathbf{K}$ & $\mathrm{Ca}$ & Mg & B & $\mathrm{Cu}$ & $\mathrm{Fe}$ & $\mathrm{Zn}$ & $\mathrm{Na}$ & As & $\mathrm{Cd}$ & $\mathrm{Cr}$ & $\mathbf{P b}$ & $\mathrm{Hg}$ & $\mathrm{pH}$ & $\mathbf{E} C^{* *}$ \\
\hline $\mathrm{CM}$ & 3 & 2 & 3 & 10,632 & 3900 & 279 & 117 & 259 & 424 & 5558 & 1.9 & 0 & 4 & 0.9 & 1.9 & 7.8 & 5.8 \\
\hline DM & 0.5 & 0.5 & 0.5 & 9833 & 357 & 69 & 7 & 164 & 74 & 451 & 1.7 & 0.1 & 2 & 1.3 & 7.8 & 8.2 & 3.4 \\
\hline MG & 5 & 4 & 0 & 6140 & 2171 & 102 & 45 & 2154 & 220 & 851 & 2.9 & 0.2 & 18 & 15.2 & 0 & 6.1 & 3.8 \\
\hline
\end{tabular}

* OA = Organic Amendment, CM = Chiken Manure, DM = Dairy Manure, MG = Milorganite, ${ }^{* *}$ Electrical Conductivity (EC) unit mS $\mathrm{cm}^{-1}$, Nitrogen $(\mathrm{N})$, Phosphate $(\mathrm{P})$, Potash $(\mathrm{K})$, Calcium $(\mathrm{Ca})$, Magnesium $(\mathrm{Mg})$, Boron $(\mathrm{B})$, Copper $(\mathrm{Cu})$, Iron $(\mathrm{Fe})$, Zinc $(\mathrm{Zn})$, Sodium $(\mathrm{Na})$, Arsenic (As), Cadmium (Cd), Chromium (Cr), Lead (Pb), Mercury (Hg).

The layout of a $3 \times 4$ factorial experimental design, with three organic amendment types (chicken manure, dairy manure, and MilorganiteTM) and four rates $(0,168,336$, and $672 \mathrm{~kg} \mathrm{~N} / \mathrm{ha}$ ) arranged in a randomized complete block design with three replications is shown in Figure 1. The organic amendments applied to each plot were mixed into the top $15 \mathrm{~cm}$ of the soil using hoes and rakes. Plots were seeded with collard greens in October 2017. A three-line-drip irrigation system was installed at each bed. All experimental plots were uniformly hand-weeded throughout the growing season.

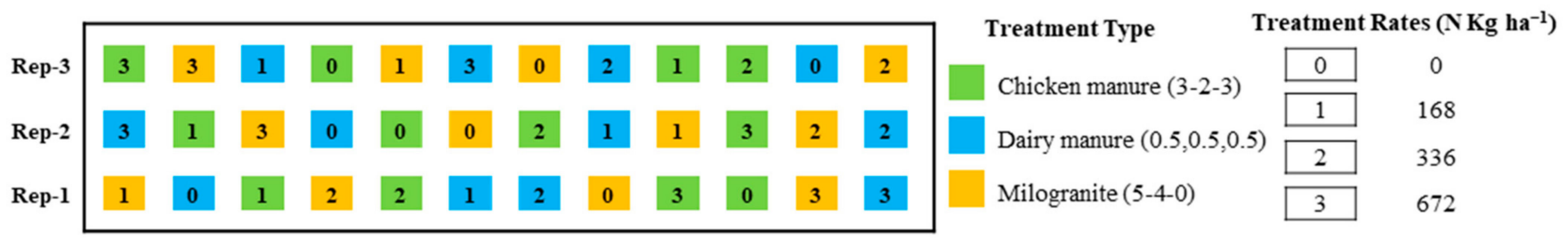

Figure 1. The layout of the experimental field showing twelve amendment combinations (including chicken manure, dairy manure, and Milorganite ${ }^{\mathrm{TM}} \times$ application rate $0,168,336$, and $672 \mathrm{~kg}$ of total nitrogen per hectare) replicated thrice in thirty-six experimental plots in a factorial design. 


\subsection{Data Collection and Analysis}

Soil suction cups were installed before sowing at 15 and $45 \mathrm{~cm}$ depths to collect soil solution samples within and below the crop rootzone. Soil solutions were collected six times during the growing season from each plot and analyzed for macro- $(\mathrm{TN}, \mathrm{P}, \mathrm{K}, \mathrm{Na}, \mathrm{Ca}$, and $\mathrm{Mg}$ ) and micronutrients $(\mathrm{B}, \mathrm{Cu}, \mathrm{Fe}$, and $\mathrm{Zn})$. It is considered that the $\mathrm{TN}$ concentration reported in the Results section may contain both organic $\mathrm{N}$ and the mineralized content of the $\mathrm{N}$; however, the mineral contents of $\mathrm{N}\left(\mathrm{NH}_{3}-\mathrm{N}\right.$ or $\left.\mathrm{NH}_{4}-\mathrm{N}\right)$ were not separately determined and are not discussed as such. Daily weather data were collected using a weather station that was installed at the site. Irrigation was scheduled based on soil oisture availability and considering the rainfall and crop growth stages. Daily rainfall, irrigation, and soil solution sampling dates are shown in Figure 2.

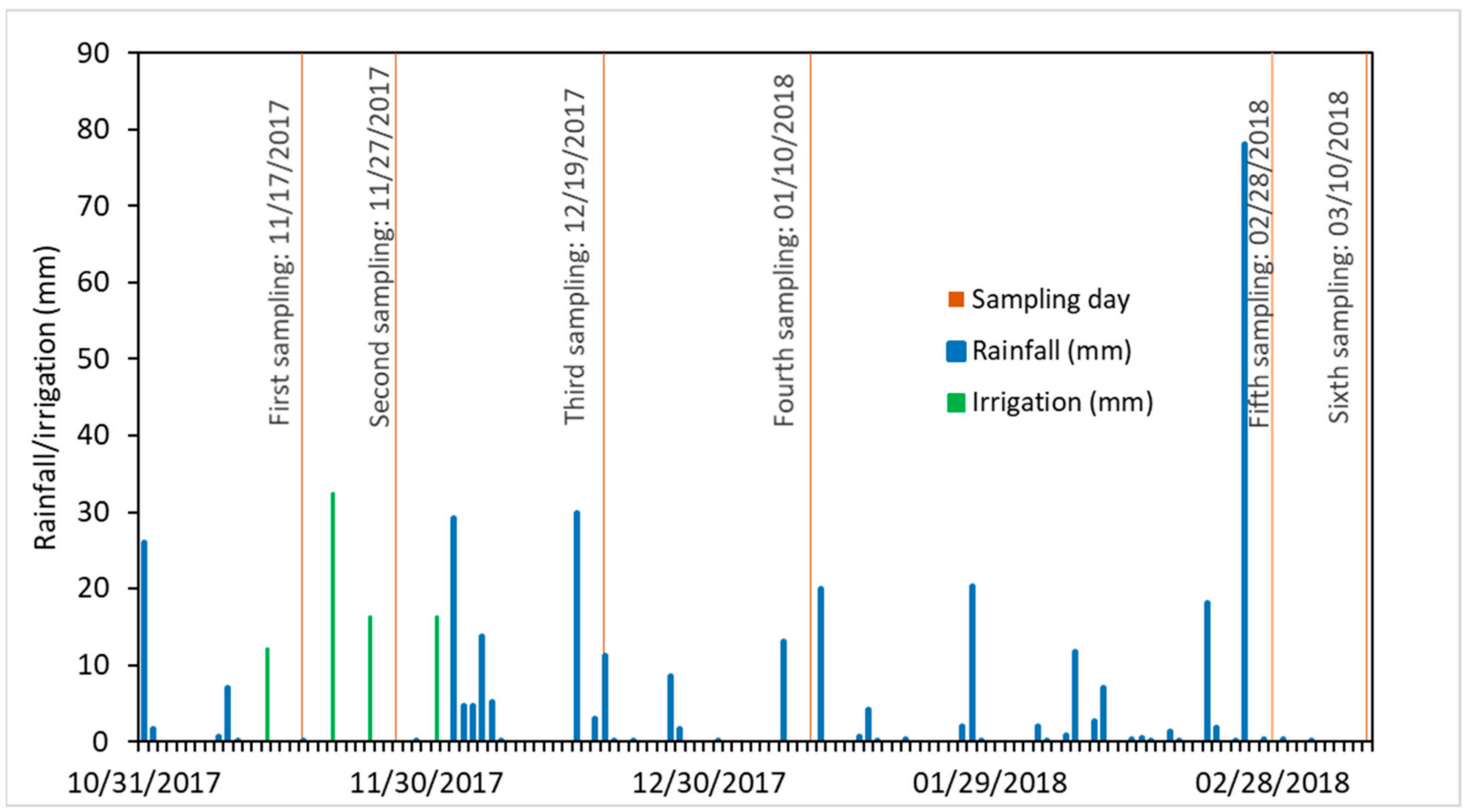

Figure 2. Daily rainfall, supplemental irrigation, and six sampling events during the growing season.

All water samples were filtered with $45 \mu \mathrm{m}$ filters (Millex-HA, Merck Millipore Ltd., Darmstadt, Germany), and analyzed in triplicates for TN, P, K, Na, Ca, Mg, B, Cu, Fe, and $\mathrm{Zn}$ using inductively coupled plasma-optical emission spectrometry (ICP-OES).

The study hypothesis was tested by calculating analysis of variance (ANOVA) for the selected within- and below-rootzone macro- and micronutrients, under the effects of type and rate of soil amendments, using Statistix software package (Analytical Software 2003, Tallahassee, FL). Macro- and micronutrients were dependent variables, and the rate and type of soil amendments were covariance factors. Tukey's mean separation (least significant difference) test was used to separate the effect of type and rate of soil amendments on macro- and micronutrients when statistically significant effects and/or interactions were found between the factors.

\section{Results and Discussions}

As hypothesized, the dynamics of most of the macro- and micronutrients studied significantly varied within and below the rootzone of collard greens differently under the effects of organic amendment types (chicken manure, dairy manure, and Milorganite ${ }^{\mathrm{TM}}$ ) 
and application rates $(0,168,336,672 \mathrm{~kg}$ total $\mathrm{N} / \mathrm{ha})$. The categorized results are presented and discussed below.

\subsection{Macronutrients within the Rootzone}

Organic amendment types and rates had significant $(p<0.05)$ and highly significant $(p$ $<0.01$ ) effects on dynamics of macronutrients at varying times within and below the rootzone of collard greens (Table 3). Significant interactions of types and rates of amendments were also recorded for TN and $\mathrm{P}$ in the rootzone and $\mathrm{K}$ below the rootzone. Asymmetrical variations in macronutrient concentrations may be related to the variation of mineralization rates as a result of the edaphic conditions and due to poor distribution of rainfall events during the growing season (Figure 2). Increased soil moisture resulted in the release of nutrients from applied amendments to the soil and their presence in soil water samples collected in the suction cups [42]. The release of nutrients depended on the amount of soil moisture and time lapse after the amendments were mixed into the soil. Data presented in Table 3 show that most of the nutrient releases occurred during the second, third, fourth, and fifth collection periods. Concentrations of nutrients during the second sampling period were likely influenced by supplemental irrigation. The concentrations during the third and fifth sampling periods were due to rainfall received, and during the fourth sampling period, it was probably due to the time lapse between the last irrigation intakes and sample collection time. These results concur with the findings of Basso and Ritchie [43] and [44], who reported that soil moisture is one of the main factors that affect manure decomposition and mineralization.

Table 3. Analysis of variance (ANOVA) results for the concentration of macronutrients (TN: total nitrogen, P: phosphorous, $\mathrm{K}$ : potassium, Ca: calcium, and Mg: magnesium) in samples collected from and below the rootzone six times during the growing season. The bold symbols reflect the mean of these nutrients as highly significantly $(p<0.01)$ and the regular symbols reflect the mean of these nutrients as significantly $(p<0.05)$ different as well as higher than the respective mean values of these nutrients detected in the control treatments under the effects of amendment types, rates, or their interactions.

\begin{tabular}{|c|c|c|c|c|c|c|c|c|c|c|c|c|c|}
\hline \multirow[b]{2}{*}{ SOV } & \multirow[b]{2}{*}{ df } & \multicolumn{6}{|c|}{ Within-Rootzone Collection Time } & \multicolumn{6}{|c|}{ Below-Rootzone Collection Time } \\
\hline & & 1 & 2 & 3 & 4 & 5 & 6 & 1 & 2 & 3 & 4 & 5 & 6 \\
\hline Block & 2 & & & & & & & & & & & & $\mathrm{Mg}$ \\
\hline Type & 2 & $\mathbf{K}$ & $\mathbf{P}, \mathrm{K}, \mathrm{Na}$ & & TN, $\mathbf{P}$ & $\begin{array}{c}\text { TN, P, K, } \\
\mathrm{Na}, \mathrm{Mg}, \mathrm{Ca}\end{array}$ & & K & & & $\begin{array}{c}\text { TN, P, Ca, } \\
\text { Mg }\end{array}$ & TN & $\mathrm{TN}, \mathrm{Ca}$ \\
\hline Rate & 3 & $\mathbf{K}$ & $\begin{array}{c}\text { P, K, } \mathrm{Na} \\
\mathrm{Ca}, \mathrm{Mg}\end{array}$ & $\begin{array}{c}\mathrm{TN}, \mathbf{P}, \mathrm{K}, \\
\mathrm{Ca}, \mathrm{Mg}\end{array}$ & $\begin{array}{c}\text { TN, P, Na, } \\
\text { Ca, Mg }\end{array}$ & $\begin{array}{l}\text { TN, } \mathbf{P}, \mathbf{N a}, \\
\text { Ca, } \mathrm{Mg}\end{array}$ & $\begin{array}{l}\mathrm{TN}, \mathrm{Na}, \\
\mathrm{Ca}, \mathrm{Mg}\end{array}$ & $\mathbf{P}$ & & $\mathrm{P}$ & $\begin{array}{l}\text { TN, P, Ca, } \\
\quad \text { Mg }\end{array}$ & $\mathrm{Ca}, \mathrm{Mg}$ & $\mathrm{Ca}, \mathrm{Mg}$ \\
\hline Type $\times$ Rate & 6 & & $\mathbf{P}$ & & $\mathrm{P}$ & TN, P & & & & & & TN & $\mathrm{K}$ \\
\hline Error & 19 & & & & & & & & & & & & \\
\hline Total & 32 & & & & & & & & & & & & \\
\hline
\end{tabular}

$\mathrm{SOV}$, sources of variation; df, degree of freedom.

The effect of types of organic amendments on the release of macronutrients is shown in Figure 3. Chicken manure and Milorganite ${ }^{\mathrm{TM}}$ released significantly more TN than did dairy manure during the fourth and fifth sampling periods. The differences were more than double during the fourth sampling period and more than triple during the fifth sampling period. This was probably due to the difference in the higher original $\mathrm{N}$ content in chicken manure and Milorganite ${ }^{\mathrm{TM}}$ than in dairy manure (Table 2). These results are in concurrence with the findings of Eghball et al. [45]. They reported that the mineralization of organic $\mathrm{N}$ was low for composted manure $(\sim 18 \%)$ and high for swine and/or chicken manure ( 55\%). Eghball [46] related lower $\mathrm{N}$ availability from composted manures to the loss of easily convertible $\mathrm{N}$ compounds during composting and the presence of stable $\mathrm{N}$ compounds. Results from the 16-day incubation trials of Aulakh et al. [47] show that cattle manure's mineralization $\mathrm{N}$, presumed $\mathrm{N}$, poultry (chicken) manure $\mathrm{N}$, and green manure $\mathrm{N}$ were $12,20,29$, and $44 \%$, respectively. Varying $\mathrm{N}$ release was likely due to the differences in the rate of mineralization of various manures. However, $\mathrm{P}$ release from Milorganite ${ }^{\mathrm{TM}}$ remained slower than the other two manures despite its 
significantly higher original content in Milorganite ${ }^{\mathrm{TM}}$. This confirms its designation as a slow P-releasing product and its low potential of contaminating neighboring surface water bodies. Phosphorus is a surface water pollutant carried by eroded sediment particles into surface waters (https:/ / www.milorganite.com/using-milorganite/safety, accessed on 12 January 2020). Alleoni et al. [48] reported that there was $14 \%$ less bioavailable P in the runoff samples from Milorganite ${ }^{\mathrm{TM}}$ treatment than triple superphosphate.
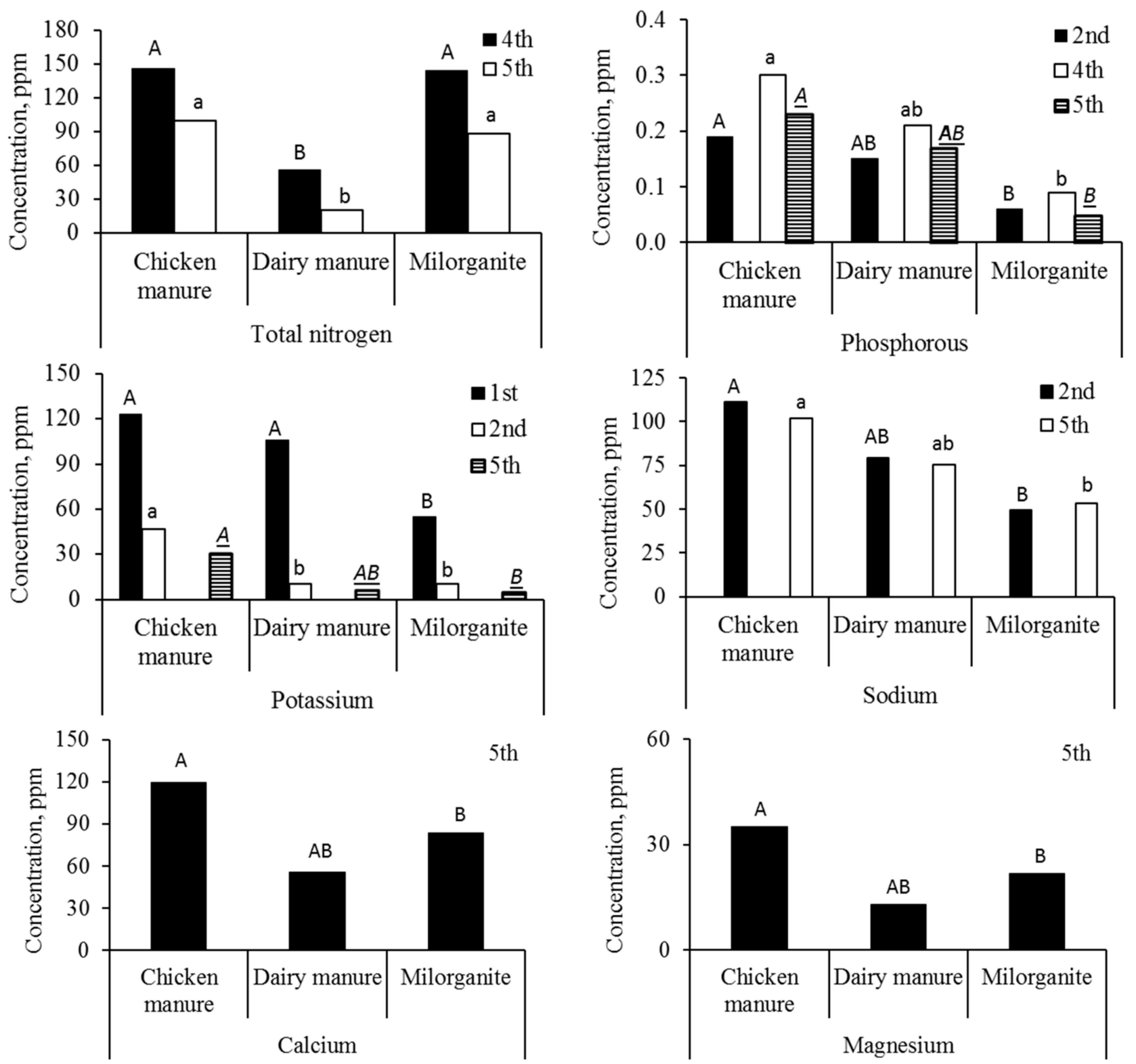

Figure 3. Effect of type of amendments (chicken manure, dairy manure, and Milorganite ${ }^{\mathrm{TM}}$ ) on macronutrients' (total nitrogen, phosphorous, potassium, sodium, calcium, and magnesium) dynamics in the crop rootzone. Tukey's mean separation results are shown by homogeneous group letters; that is, the mean values with letters $\mathrm{A}$, a, or $\underline{A}$ are significantly different (and large) from those represented by respective (upper/lower case or underlined italic) letters other than A, a, or $\underline{A}$ and not different from those represented with same respective letter or its combination with any other letter(s), for example, $\mathrm{AB}$ and $\mathrm{ab}$.

Literature, e.g., $[49,50]$ has reported that high levels of $\mathrm{P}$ (e.g., $4 \%$ in Milorganite $^{\mathrm{TM}}$ as compared to 2 and $0.5 \%$ in chicken and dairy manures, respectively, as shown in Table 2) can reduce the formation of Vesicular-Arbuscular (VA) mycorrhizae. VA mycorrhiza is a fungus with the ability to dissolve the P found in abundance in the soil. VA mycorrhizae 
have limited inhibition in the Milorganite ${ }^{\mathrm{TM}}$ amended soils [51]. Therefore, the lack of VA mycorrhizae may be attributed to a slower release of available $\mathrm{P}$ in Milorganite ${ }^{\mathrm{TM}}$ treatment. The lower availability of $\mathrm{P}$ ions in Milorganite ${ }^{\mathrm{TM}}$ may have been accentuated by the atypically dry growing season (especially during December and January), thus slowing the release and assimilation of $\mathrm{P}$ even further similar to the findings of Arnold and Kapustka [51].

There were similar trends in the dynamics of $\mathrm{K}$ (first, second, and fifth collection periods), $\mathrm{P}$ (second, fourth, and fifth collection periods), and $\mathrm{Na}$ (second and fifth collection periods) when chicken manure was quicker in releasing these macronutrients and had higher concentrations of these macronutrients than those of Milorganite ${ }^{\mathrm{TM}}$ (Figure 3). Calcium and $\mathrm{Mg}$ were only detected in the leachates of the rootzone during the fifth sampling period. Their higher concentrations released from chicken manure followed a similar trend as those of $\mathrm{K}$ and $\mathrm{Na}$. The higher concentrations of $\mathrm{K}, \mathrm{Ca}, \mathrm{Na}$, and $\mathrm{Mg}$ releases may be attributed to their higher presence in chicken manure than in Milorganite ${ }^{\mathrm{TM}}$. The release of $\mathrm{Ca}$ and $\mathrm{Mg}$ from dairy manure was not significantly different from those of the chicken manure and Milorganite ${ }^{\mathrm{TM}}$ treatments. Milorganite ${ }^{\mathrm{TM}}$ had higher $\mathrm{Mg}$ content than dairy manure, and thus, there were higher $\mathrm{Mg}$ releases from Milorganite than from dairy manure, although it was not statistically significant (Table 3, Figure 3). The trends of $\mathrm{TN}, \mathrm{Ca}$, and $\mathrm{Mg}$ were similar whenever they were detected within the crop rootzone by showing higher concentrations from the release of chicken manure and Milorganite ${ }^{\mathrm{TM}}$ than dairy manure (Figure 3).

\subsection{Macronutrients below the Rootzone}

The impact of the organic amendment types and rates on the macronutrients below the rootzone was more pronounced than within the rootzone. In addition, there were significant effects of the organic amendment types and rates during the fourth to sixth sampling periods (Table 4$)$. Amendment types had a highly significant $(p<0.01)$ effect on TN during the fourth to sixth sampling periods; moreover, amendment rates had a significant effect on TN during the fourth sampling period and a significant interaction between types and rates during the fifth sampling period. This reflects TN's tendency to leach, mostly in the form of nitrate $\left(\mathrm{NO}_{3}-\mathrm{N}\right)$. Nitrate produced from $\mathrm{N}$ mineralization is leached below the rootzone potentially to the groundwater if applied excessively to the agricultural fields through fertilizers [52]. Excessive or over-application of fertilizers might have resulted in significantly higher concentrations of TN in leachates collected from treatments of chicken manure and Milorganite ${ }^{\mathrm{TM}}$ than in dairy manure treatments (Figure 4).

Table 4. Analysis of variance (ANOVA) results for the concentration of micronutrients (B: boron, Cu: copper, Fe: iron, and Zn: zinc) in samples collected from and below rootzone six times during the growing season. The bold symbols reflect the mean of these nutrients as highly significantly $(p<0.01)$ and the regular symbols reflect the mean of these nutrients as significantly $(p<0.05)$ different as well as higher than the respective mean values of these nutrients detected in the control treatments under the effects of amendment types, rates, or their interactions.

\begin{tabular}{cccccccccccc}
\hline & \multicolumn{1}{c}{ Within-Rootzone Collection Time } & \multicolumn{3}{c}{ Below-Rootzone Collection Time } \\
\hline SOV & DF & $\mathbf{1}$ & $\mathbf{2}$ & $\mathbf{3}$ & $\mathbf{4}$ & $\mathbf{5}$ & $\mathbf{6}$ & $\mathbf{1}$ & $\mathbf{2}$ & $\mathbf{3}$ & $\mathbf{4}$ \\
\hline Block & 2 & & & & & & & & \\
Type & 2 & B & B, Cu, Fe & B, Cu & B, Cu & B & B & Cu & \\
Rate & 3 & & B, Cu & B & Zn & Zn & Zn & & & \\
Type $\times$ Rate & 6 & B, Fe & B, Cu & B & & & & Fe & \\
Error & 19 & & & & & & & & \\
Total & 32 & & & & & & & & \\
\hline
\end{tabular}



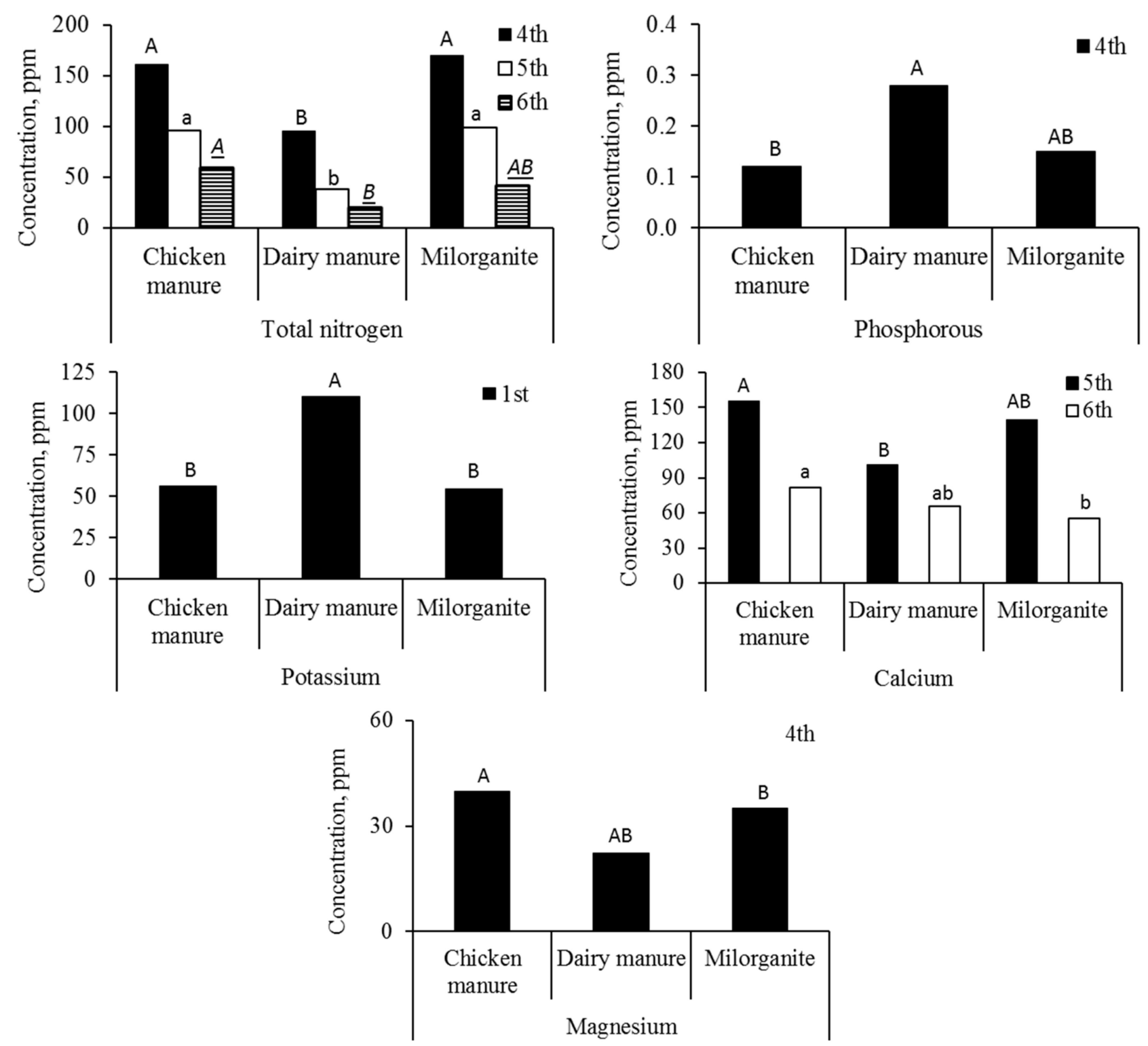

Figure 4. Effect of type of amendments (chicken manure, dairy manure, and Milorganite ${ }^{\mathrm{TM}}$ ) on macronutrients' dynamics (total nitrogen, phosphorous, potassium, calcium, and magnesium) below crop rootzone. Tukey mean separation results are shown by homogeneous group letters; that is, the mean values with letters $\mathrm{A}$, a, or $\underline{A}$ are significantly different (and large) from those represented by respective (upper/lower case or underlined italic) letters other than $\mathrm{A}$, a, or $\underline{A}$ and not different from those represented with same respective letter or its combination with any other letter(s), for example, $A B$ and ab.

Results of the statistical analysis presented in Table 3 show that there was a significant effect of amendment types on the dynamics of $\mathrm{P}, \mathrm{K}, \mathrm{Mg}$, and Ca below the crop rootzone $(p<0.05)$. However, there was a highly significant effect of rate of amendment application on the below-rootzone concentrations of $\mathrm{P}, \mathrm{Ca}$, and $\mathrm{Mg}(p<0.01)$. The application of chicken manure and Milorganite ${ }^{\mathrm{TM}}$ resulted in higher below-the-rootzone leachate concentration of $\mathrm{TN}, \mathrm{Mg}$, and $\mathrm{Ca}$ than in the leachates of dairy manure (Figure 4). This may be due to three-fold higher $\mathrm{N}$ mineralization rates of chicken manure (55\%) compared to that of composted manure (18\%) as reported by Eghball et al. [45]. Furthermore, they stated that $\mathrm{P}$ availability from all animal manure production sources is as high as $>70 \%$; since most of the manure $\mathrm{P}$ is inorganic, it becomes plant-available right after manure application to soil. Further to it, they stated that $\mathrm{K}$ availability from animal manure is nearly $100 \%$; therefore, animal manure can be used similar to K fertilizer. Leytem et al. [53] evaluated the cycling of $\mathrm{P}$ and $\mathrm{N}$ through cropping systems in an intensive dairy production region of Magic Valley 
located in the southcentral Idaho (USA) and concluded that there are benefits to applying livestock manures as they can provide large amounts of $\mathrm{N}$ and $\mathrm{P}$ as well as a variety of additional macro- and micronutrients [54] to growing crops probably because the animal manures are rich in nutrients than other organic manures [55]. The movement of nutrients is also related to soil physicochemical properties that are impacted by manure types. Sandy soils and soils with high sand content, such as the soil of this experiment, (Table 1) have lower cation exchange and low water holding capacity than fine-texture soils, resulting in low water and nutrient retentions and resulting in nutrients' leaching below the rootzone of crops grown on these soils. Blanco-Canqui et al. [56] reported significant improvements in the soil properties of the top $30 \mathrm{~cm}$ layers of sandy loam soils in Nebraska in response to long-term (71 years) manure applications as compared to soils amended with inorganic fertilization. They found that across $\mathrm{N}$ levels, manure application reduced soil bulk density by $6 \%$, increased soil water holding capacity by about $17 \%$, resulting in about $16 \%$ more plant available water than manure-free plots. Soil organic carbon concentration increased by two-fold while negatively correlating with soil compatibility $(\mathrm{r}>-0.77)$ and positively with water retention $(r>0.72)$. Higher release of $K$ from dairy manure than the other major macronutrients was also confirmed by Motavalli et al. [57], who studied the first-year nutrient availability from incorporated dairy manure under corn and reported that $\mathrm{K}$ was highly available (24-153\%) to the plants followed by P (12 to $89 \%$ ) and N (12 to $63 \%)$. Hepperly et al. [58] reported increases in crop productivity and soil fertility in response to applying raw cattle manure or composted manure for a longer term than synthetic fertilizers. They argued that since synthetic fertilizers have higher energy requirements, they pose nitrate leaching potential and cannot improve $\mathrm{N}$ and $\mathrm{C}$ soil nutrient levels of soil over a more extended period.

\subsection{Micronutrients within the Rootzone}

Boron concentration varied significantly or highly significantly in response to the effect of amendment type during all six sampling periods (Table 4). However, the amendment application rate had significant effects on B concentrations during the second and third sampling periods only, whereas the interaction of amendment types and rates significantly affected $\mathrm{B}$ dynamics during the first three sampling periods. The other three micronutrients $(\mathrm{Cu}, \mathrm{Fe}$, and $\mathrm{Zn})$ showed different responses to amendment types, rates, and their interaction during the various sampling periods. Copper showed varying dynamics during the second to fourth periods; however, Fe concentration varied during the first two sampling periods, and $\mathrm{Zn}$ concentration varied during fourth to sixth periods only.

Most of the $\mathrm{B}, \mathrm{Cu}$, and $\mathrm{Fe}$ releases were during the initial sampling period for treatments of all three organic amendments (Figure 5). Chicken manure had significant and higher releases than the other two amendments; during the respective six sampling periods, it released $17,101,31,322,297$, and $147 \%$ and $27,119,43,536,568$, and $151 \%$ more $B$ than dairy manure and Milorganite ${ }^{\mathrm{TM}}$, respectively. The release of $\mathrm{Cu}$ from chicken manure was substantially enormous compared to its release from the other two amendments. Release of Fe from chicken manure was 270 and $720 \%$ more than those from dairy manure and Milorganite $^{\mathrm{TM}}$, respectively. 

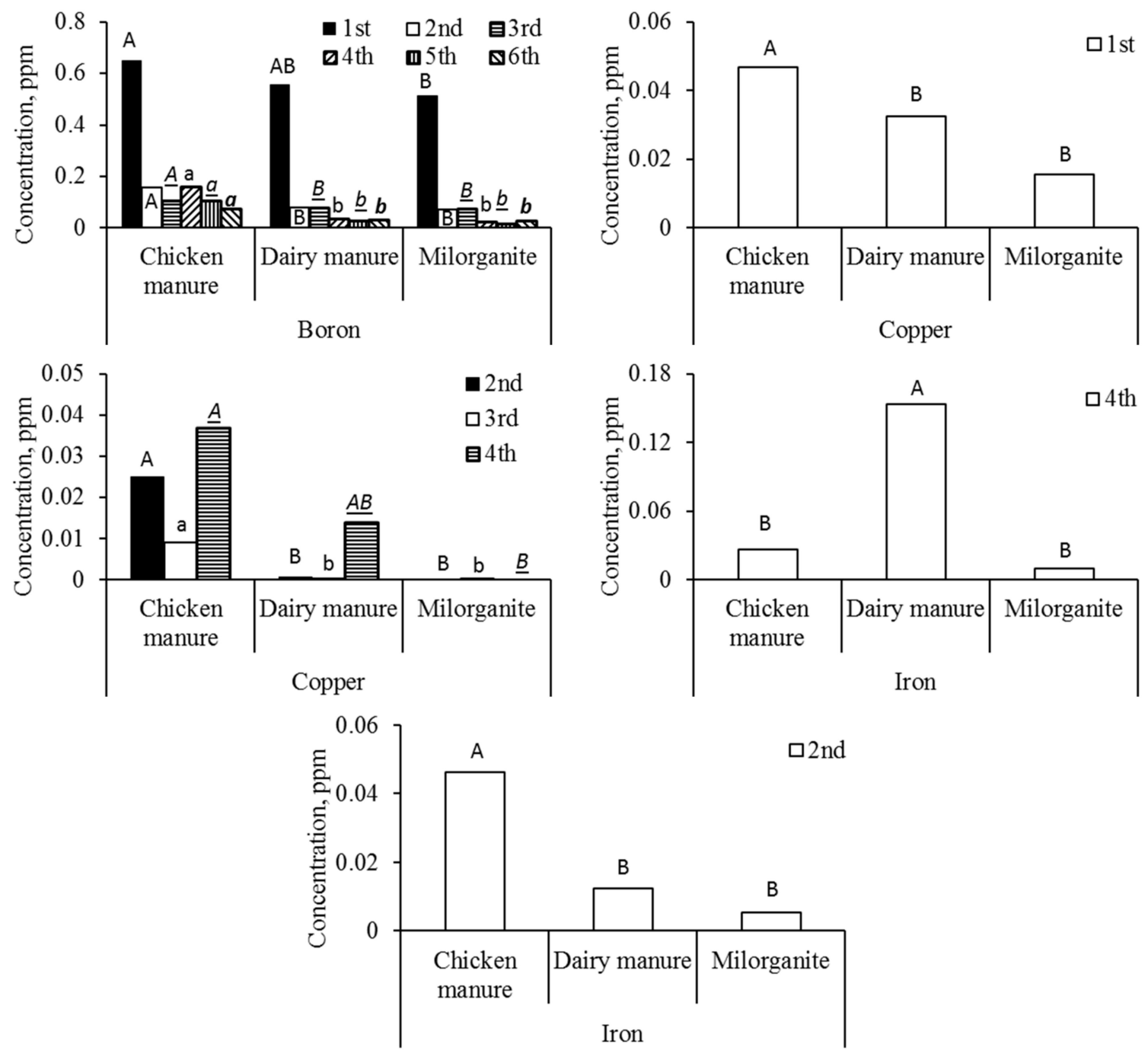

Figure 5. Effect of type of amendments (chicken manure, dairy manure, and Milorganite ${ }^{\mathrm{TM}}$ ) on dynamics of micronutrients (boron, copper, and iron) in crop rootzone (left column) and below rootzone (right column). Tukey's mean separation results are shown by homogeneous group letters; that is, the mean values with letters $\mathrm{A}$, a, or $\underline{A}$ are significantly different (and large) from those represented by respective (upper/lower case or underlined italic) letters other than $\mathrm{A}$, a, or $\underline{A}$ and not different from those represented with same respective letter or its combination with any other letter(s), for example, $A B$ and $a b$.

\subsection{Micronutrients below the Rootzone}

Copper and Fe were the only micronutrients that leached below the rootzone during the first and fourth sampling periods, respectively, under the significant effect of amendment types (Table 4). There was also a significant interaction between types and rates of amendments for Fe below the rootzone. The mean concentration of $\mathrm{Cu}$ released from the nutrient-rich chicken manure was significantly different and $44.4 \%$ higher from the mean value of $\mathrm{Cu}$ released from dairy manure and 108\% higher from that released by Milorganite ${ }^{\mathrm{TM}}$. In contrast, Fe released from dairy manure was significantly different and 476 and $1438 \%$ higher in dairy manure than in chicken manure and Milorganite ${ }^{\mathrm{TM}}$, respectively. Overall, there was no considerable leaching of micronutrients below the rootzone of collard greens from all types and rates of organic amendments compared to macronutrients (Tables 3 and 4).

\subsection{Effect of Rate of Amendment Applications}

Table 5 contains ANOVA results for the concentration of macronutrients in soil water samples collected from and below rootzone for six sampling periods during the growing 
season as affected by the four application rates including control (C), high (HR), medium (MR), and low (LR). Tukey's mean separation results show that the treatments of HR had a significantly greater and almost double concentration of all macronutrients in the rootzone. The macronutrient concentrations in the rootzone for the treatment of LR had a non-significant difference from values of the treatment of MR. Non-significant differences between the concentrations of MR and LR reflect the abundance of macronutrients available for plant needs and their potential leaching below the rootzone in case of excessive water resulting from rain or irrigation. Such situations in the field can be avoided through controlled water application to agricultural fields. Although the farmers cannot control rain, proper irrigation scheduling can prevent the leaching of unused plant nutrients in case of continuous drought periods. Changing patterns of rain caused by climate change would bring possible drought, necessitating irrigation of crops for parts of the world that are rain-fed and do not currently need supplemental irrigation [59].

Table 5. Analysis of variance (ANOVA) results for the concentration of macronutrients (ppm) in samples collected from and below rootzone six times during the growing season as affected by application rates (C: control, HR: high rates, MR: medium rates, and LR: low rates). Tukey's mean separation results are shown by homogeneous group letters, that is, a mean value with letter A or a is significantly different (and large) from those represented by letters other than A or a and not different from those represented with the same respective letter or its combination with any other letter(s), for example, $\mathrm{AB}$ and $\mathrm{ab}$.

\begin{tabular}{|c|c|c|c|c|c|c|c|c|c|c|c|c|c|}
\hline \multirow{2}{*}{$\begin{array}{l}\text { Application } \\
\text { Rates }\end{array}$} & & \multicolumn{6}{|c|}{ Within-Rootzone Collection Time } & \multicolumn{6}{|c|}{ Below-Rootzone Collection Time } \\
\hline & & 1 & 2 & 3 & 4 & 5 & 6 & 1 & 2 & 3 & 4 & 5 & 6 \\
\hline $\mathrm{C}$ & $\begin{array}{c}\text { Total } \\
\text { nitrogen }\end{array}$ & - & - & $104^{B}$ & $56.8^{\mathrm{B}}$ & $29.9^{\mathrm{A}}$ & $14.2^{\mathrm{B}}$ & - & - & - & $122^{B}$ & - & - \\
\hline HR & & - & - & $196^{\mathrm{A}}$ & $157^{\mathrm{AB}}$ & $104^{\mathrm{A}}$ & $61.5^{\mathrm{A}}$ & - & - & - & $175^{\mathrm{A}}$ & - & - \\
\hline MR & & - & - & $172 \mathrm{AB}$ & $174^{\mathrm{A}}$ & $103^{\mathrm{A}}$ & $46.0^{\mathrm{AB}}$ & - & - & - & $154^{\mathrm{AB}}$ & - & - \\
\hline LR & & - & - & $107^{\mathrm{AB}}$ & $73.1 \mathrm{AB}$ & $41.0^{\mathrm{AB}}$ & $14.8^{\mathrm{B}}$ & - & - & - & $118^{\mathrm{B}}$ & - & - \\
\hline $\mathrm{C}$ & Phosphorous & - & $0.06^{\mathrm{B}}$ & $0.05^{\mathrm{B}}$ & $0.09^{\mathrm{B}}$ & $0.05^{\mathrm{B}}$ & - & $0.31^{\mathrm{B}}$ & & $0.04^{\mathrm{B}}$ & $0.11^{\mathrm{B}}$ & - & - \\
\hline HR & & - & $0.26^{\mathrm{A}}$ & $0.19^{\mathrm{A}}$ & $0.35^{\mathrm{A}}$ & $0.30^{\mathrm{A}}$ & - & $0.80^{\mathrm{A}}$ & & $0.15^{\mathrm{A}}$ & $0.33^{\mathrm{A}}$ & - & - \\
\hline MR & & - & $0.13^{\text {в }}$ & $0.08^{\mathrm{B}}$ & $0.22 \mathrm{AB}$ & $0.15^{\mathrm{AB}}$ & - & $0.52 \mathrm{AB}$ & & $0.06^{\mathrm{AB}}$ & $0.19 \mathrm{AB}$ & - & - \\
\hline LR & & - & $0.09^{\mathrm{B}}$ & $0.05^{\text {B }}$ & $0.15^{\mathrm{AB}}$ & $0.09^{\mathrm{B}}$ & - & $0.19^{\mathrm{B}}$ & & $0.05^{\mathrm{AB}}$ & $0.11^{\text {В }}$ & - & - \\
\hline $\mathrm{C}$ & Potassium & $57.5^{\mathrm{B}}$ & $6.49^{\mathrm{B}}$ & $7.90^{\mathrm{B}}$ & - & - & - & - & - & - & - & - & $1.44^{\mathrm{AB}}$ \\
\hline HR & & $144^{\mathrm{A}}$ & $56.7^{\mathrm{A}}$ & $34.7^{\mathrm{A}}$ & - & - & - & - & - & - & - & - & $1.58 \mathrm{AB}$ \\
\hline MR & & $120^{\mathrm{A}}$ & $23.6^{\mathrm{AB}}$ & $22.0^{\mathrm{AB}}$ & - & - & - & - & - & - & - & - & $0.96^{\mathrm{B}}$ \\
\hline LR & & $56.1^{\text {В }}$ & $2.88^{\mathrm{B}}$ & $10.2^{\mathrm{AB}}$ & - & - & - & - & - & - & - & - & $3.39^{\mathrm{A}}$ \\
\hline $\mathrm{C}$ & Sodium & - & $45.3^{B}$ & - & $39.2^{\mathrm{B}}$ & $33.3^{C}$ & $33.7^{\mathrm{B}}$ & - & - & - & - & - & - \\
\hline HR & & - & $123^{\mathrm{A}}$ & - & $116^{\mathrm{A}}$ & $115^{\mathrm{A}}$ & $128^{\mathrm{A}}$ & - & - & - & - & - & - \\
\hline MR & & - & $98.0 \mathrm{AB}$ & - & $113^{\mathrm{A}}$ & $107^{\mathrm{AB}}$ & $104^{\mathrm{AB}}$ & - & - & - & - & - & - \\
\hline LR & & - & $53.5^{\mathrm{AB}}$ & - & $62.5^{\mathrm{AB}}$ & $51.4^{\mathrm{BC}}$ & $50.4^{\text {в }}$ & - & - & - & - & - & NS \\
\hline $\mathrm{C}$ & Calcium & - & $92.4^{\mathrm{B}}$ & $119^{\mathrm{B}}$ & $56.2^{\text {B }}$ & $38.6^{\mathrm{C}}$ & $29.7^{\mathrm{C}}$ & - & - & - & $122^{\mathrm{B}}$ & $71.6^{\mathrm{B}}$ & $101^{\mathrm{B}}$ \\
\hline HR & & - & $222^{\mathrm{A}}$ & $250^{\mathrm{A}}$ & $157^{\mathrm{A}}$ & $134^{\mathrm{A}}$ & $113^{\mathrm{A}}$ & - & - & - & $175^{\mathrm{A}}$ & $185^{\mathrm{A}}$ & $189^{\mathrm{A}}$ \\
\hline MR & & - & $199 \mathrm{AB}$ & $220^{A}$ & $140 \mathrm{AB}$ & $116^{\mathrm{AB}}$ & $94.5^{\mathrm{AB}}$ & - & - & - & $154^{\mathrm{AB}}$ & $104^{\mathrm{B}}$ & $135^{\mathrm{B}}$ \\
\hline LR & & - & $118^{\mathrm{AB}}$ & $146^{\mathrm{A}}$ & $75.7^{\mathrm{AB}}$ & $57.6^{\mathrm{BC}}$ & $45.8^{\mathrm{BC}}$ & - & - & - & $118^{\mathrm{B}}$ & $71.6^{\mathrm{B}}$ & $103^{\mathrm{B}}$ \\
\hline C & Magnesium & - & $23.0^{\mathrm{B}}$ & $30.3^{B}$ & $14.3^{\mathrm{B}}$ & $8.90^{\mathrm{B}}$ & $7.35^{\mathrm{C}}$ & - & - & - & $23.9^{\mathrm{B}}$ & $15.3^{B}$ & $10.2^{\mathrm{B}}$ \\
\hline HR & & - & $61.0^{\mathrm{A}}$ & $71.4^{\mathrm{A}}$ & $50.3^{\mathrm{A}}$ & $38.4^{\mathrm{A}}$ & $36.0^{\mathrm{A}}$ & - & - & - & $48.4^{\mathrm{A}}$ & $46.6^{\mathrm{A}}$ & $24.4^{\mathrm{A}}$ \\
\hline MR & & - & $55.9^{\mathrm{AB}}$ & $66.2^{\mathrm{AB}}$ & $38.9^{\mathrm{AB}}$ & $30.7^{\mathrm{AB}}$ & $28.6^{\mathrm{AB}}$ & - & - & - & $33.5^{\mathrm{AB}}$ & $24.1^{\mathrm{AB}}$ & $15.5^{\mathrm{AB}}$ \\
\hline LR & & - & $28.9^{\text {B }}$ & $39.2^{\mathrm{B}}$ & $20.6^{\mathrm{AB}}$ & $15.3^{\mathrm{AB}}$ & $11.7^{\mathrm{BC}}$ & - & - & - & $24.1^{\mathrm{B}}$ & $15.5^{\mathrm{B}}$ & $13.4^{\mathrm{AB}}$ \\
\hline
\end{tabular}

Movement of all macronutrients below the rootzone was witnessed, except for $\mathrm{Na}$, during different sampling periods (Table 5). These results concur with the findings of Zotarelli et al. [60] who monitored $\mathrm{N}$ accumulation and fertilizer use efficiency in tomato grown on a Florida sandy soil, as affected by $\mathrm{N}$ rate and irrigation scheduling. They found that $\mathrm{N}$ higher application rates did not increase the fruit and/or shoot biomass of tomato but substantially increased $\mathrm{NO}_{3}-\mathrm{N}$ leaching and recommended that proper irrigation scheduling would minimize nutrient leaching from agricultural fields in sandy soils. Leaching of nutrients below the rootzone of various crops has also been related to the amount of water in the crop rootzone by other studies [61]. Boron, $\mathrm{Cu}$, and $\mathrm{Zn}$ had similar effects of amendment application rates on their dynamics in the rootzone (Table 6). However, the amendment application rates did not have any significant effect on the dynamics of micronutrients below the rootzone of collard greens. 
Table 6. Analysis of variance (ANOVA) results for the concentration of micronutrients (ppm) in samples collected from and below rootzone for six times during the growing season as affected by application rates (C: control, HR: high rates, MR: medium rates, and LR: low rates). Tukey's mean separation results are shown by homogeneous group letters, that is, a mean value with letter A or a is significantly different (and large) from those represented by letters other than A or a and not different from those represented with the same respective letter or its combination with any other letter(s), for example, $\mathrm{AB}$ and $\mathrm{ab}$.

\begin{tabular}{|c|c|c|c|c|c|c|c|c|c|c|c|c|c|}
\hline \multirow{2}{*}{$\begin{array}{l}\text { Application } \\
\text { Rates }\end{array}$} & & \multicolumn{6}{|c|}{ Within-Rootzone Collection Time } & \multicolumn{6}{|c|}{ Below-Rootzone Collection Time } \\
\hline & & 1 & 2 & 3 & 4 & 5 & 6 & 1 & 2 & 3 & 4 & 5 & 6 \\
\hline C & Boron & - & $0.07^{\mathrm{B}}$ & $0.07^{\mathrm{B}}$ & - & - & - & - & - & - & - & - & - \\
\hline HR & & - & $0.18^{\mathrm{A}}$ & $0.11^{\mathrm{A}}$ & - & - & - & - & - & - & - & - & - \\
\hline MR & & - & $0.09^{B}$ & $0.09^{\mathrm{B}}$ & - & - & - & - & - & - & - & - & - \\
\hline LR & & - & $0.08^{\mathrm{B}}$ & $0.08 \mathrm{AB}$ & - & - & - & - & - & - & - & - & - \\
\hline $\mathrm{C}$ & Copper & - & $0^{\mathrm{B}}$ & - & - & - & - & - & - & - & - & - & - \\
\hline HR & & - & $0.03^{\mathrm{A}}$ & - & - & - & - & - & - & - & - & - & - \\
\hline MR & & - & $0.01 \mathrm{AB}$ & - & - & - & - & - & - & - & - & - & - \\
\hline LR & & - & $0.0003^{\mathrm{B}}$ & - & - & - & - & - & - & - & - & - & - \\
\hline $\mathrm{C}$ & Iron & - & - & - & - & - & - & - & - & - & - & - & - \\
\hline HR & & - & - & - & - & - & - & - & - & - & - & - & - \\
\hline MR & & - & - & - & - & - & - & - & - & - & - & - & - \\
\hline LR & & - & - & - & - & - & - & - & - & - & - & - & - \\
\hline $\mathrm{C}$ & Zinc & - & - & - & $0.03^{\mathrm{B}}$ & $0.01^{\mathrm{A}}$ & $0.02^{\mathrm{B}}$ & - & - & - & - & - & - \\
\hline HR & & - & - & - & $0.11^{\mathrm{A}}$ & $0.12^{\mathrm{A}}$ & $0.08^{\mathrm{A}}$ & - & - & - & - & - & - \\
\hline MR & & - & - & - & $0.10^{\mathrm{AB}}$ & $0.07^{\mathrm{A}}$ & $0.05^{\mathrm{AB}}$ & - & - & - & - & - & - \\
\hline LR & & - & - & - & $0.03^{\mathrm{B}}$ & $0.01^{\mathrm{A}}$ & $0.02^{\mathrm{B}}$ & - & - & - & - & - & - \\
\hline
\end{tabular}

Along with the benefits of organic sources of fertilizers, the risk of buildup of heavy metals with the long-term use of soil organic amendments should not be ignored. Besides useful plant macro- and micronutrients, the organic amendments contain heavy metals, such as chromium, arsenic, selenium, nickel, and salts [62]. Therefore, organic soil amendments might add unwanted elements such as toxic heavy metals or salts, which might inhibit crop growth and reduce yield [29]. Chicken manure and Milorganite ${ }^{\mathrm{TM}}$ have been reported to have toxic micronutrients and heavy metals, including $\mathrm{Cu}, \mathrm{Zn}, \mathrm{Ni}, \mathrm{As}$, and $\mathrm{Cr}$ [63-65] potentially added to the diet of chicken manure to protect chickens from disease and improve productivity [66,67]. The long-term use and/or high rates of application of such organic soil amendments may result in a buildup of leachable heavy metals in soils to a toxic level, potentially inhibiting crop growth and reducing yield [29,68].

\section{Conclusions}

This study was conducted to understand the complex dynamics of nutrients sourced from different types and rates of soil amendment applications in the collard greens grown on sandy loam soil in Prairie View, TX, USA. There were significant and highly significant effects of amendment types and their application rates on the dynamics of the studied macro- and micronutrients within and below the rootzone. Most of the macronutrients, except $\mathrm{Na}$, remained within the rootzone with some movement below the rootzone. However, the releases of these nutrients varied with amendment types; this might be due to differences in manures' mineralization rates. Chicken manure had significantly higher $\mathrm{B}$, $\mathrm{Cu}$, and Fe releases than the other amendments as evident from the higher concentrations of its micronutrients within the rootzone of this treatment. These concentrations were significantly higher than those in the rootzone of dairy manure and Milorganite ${ }^{\mathrm{TM}}$ treatments. Chicken manure released more TN (presumably the combination of organic $\mathrm{N}$ and mineralized contents of $\mathrm{N}$ ), $\mathrm{P}, \mathrm{K}, \mathrm{Na}, \mathrm{Ca}, \mathrm{Mg}, \mathrm{B}, \mathrm{Cu}$, and $\mathrm{Fe}$ than the other two amendments. However, dairy manure treatments had the lowest concentrations of TN (supposedly comprising the organized and mineralized contents of $\mathrm{N}$ ), $\mathrm{Ca}$, and $\mathrm{Mg}$; meanwhile, Milorganite ${ }^{\mathrm{TM}}$ had the lowest presence of $\mathrm{P}, \mathrm{K}, \mathrm{Na}, \mathrm{B}$, and $\mathrm{Cu}$ in their leachates. 
Higher organic amendment application rates can substantially increase nutrient leaching, especially under excess rainfall and irrigation events, which further increase nutrient leaching from agricultural fields, especially sandy and sandy loam soils of the experimental field used for this study. The dynamics of nutrients depend on their nature, source, and the amendments application rates necessitating the need to monitor each nutrient's level in the plant material and the environment. An applied outcome of studying nutrient dynamics in the rhizosphere and below the rootzone of a crop is the ability to incorporate concepts of the best nutrient management for progressive plant growth and environmental stewardship. Selection of the best nutrient source among organic manures and the biosolids that ensure a nutrient-rich rhizosphere through the controlled release of nutrient contents from the applied soil amendments is key to profitable farming and environment-friendly sustainable agriculture.

Author Contributions: A.F. and R.A. developed the concept including the method and approach to be used; H.K.B., R.A., A.E.H., R.L.R., and A.F. contributed to the fieldwork; R.A. and A.E.H. conducted the periodical soil solution sampling and field maintenance; S.W. and A.E.H. conducted the laboratory nutrient analysis; A.E.H., R.A. and A.F. conducted the statistical analysis; A.F., R.A., and F.A. outlined, wrote, reviewed, and edited the paper. All authors have read and agreed to the published version of the manuscript.

Funding: This work was partially funded by the United States Department of Agriculture (USDA) National Institute of Food and Agriculture (NIFA), Evans-Allen projects 1004053 and 1021753, and Texas A\&M AgriLife Research.

Data Availability Statement: The data presented in this study are available on request from the corresponding author.

Acknowledgments: The authors wish to thank all students and researchers who contributed to this experiment and those who analyzed the soil water samples.

Conflicts of Interest: The authors declare that they have no conflict of interest.

\section{References}

1. Kahlon, T.S.; Chiu, M.C.M.; Chapman, M.H. Steam cooking significantly improves in vitro bile acid binding of collard greens, kale, mustard greens, broccoli, green bell pepper, and cabbage. Nutr. Res. 2008, 28, 351-357. [CrossRef] [PubMed]

2. Talwinder, S.K.; Rebecca, R.M.; Mei-Chin, M.C. In vitro bile acid binding of mustard greens, kale, broccoli, cabbage and green bell pepper improves with sautéing compared with raw or other methods of preparation. Food Nutr. Sci. 2012, 3, 951-958.

3. Takkar, P.N. Micronutrients research and sustainable agricultural productivity in India. J. Indian Soc. Soil Sci. 1996, 44, 562-581.

4. Lynch, D.H. Nutrient Cycling and Soil Health in Organic Cropping Systems-Importance of Management Strategies and Soil Resilience. Sustain. Agric. Res. 2015, 4, 80-88. [CrossRef]

5. Horel, Á.; Gelybó, G.; Potyó, I.; Pokovai, K.; Bakacsi, Z. Soil Nutrient Dynamics and Nitrogen Fixation Rate Changes over Plant Growth in Temperate Soil. Agronomy 2019, 9, 179. [CrossRef]

6. Ghosh, P.K.; Ramesh, P.; Bandyopadhyay, K.K.; Tripathi, A.K.; Hati, K.M.; Misra, A.K.; Acharya, C.L. Comparative effectiveness of cattle manure, poultry manure, phosphocompost and fertilizer-NPK on three cropping systems in vertisols of semi-arid tropics. I. Crop yields and system performance. Bioresour. Technol. 2004, 95, 77-83. [CrossRef] [PubMed]

7. Moore, P.A., Jr.; Daniel, T.C.; Gilmour, J.T.; Shreve, B.R.; Edwards, D.R.; Wood, B.H. Decreasing metal runoff from poultry litter with aluminum sulfate. J. Environ. Qual. 1998, 27, 92-99. [CrossRef]

8. Sims, J.T. Characteristics of animal wastes and waste amended soils: An overview of the agricultural and environmental issues. In Animal Waste and the Land-Water Interface, 1st ed.; Steele, K.F., Ed.; CRC: Boca Raton, FL, USA, 1995; pp. 1-14.

9. Reiter, M.S.; Daniel, T.C.; Slaton, N.A.; Norman, R.J. Nitrogen Availability from granulated fortified poultry litter fertilizers. Soil Sci. Soc. Am. J. 2014, 78, 861-867. [CrossRef]

10. Aguilera, S.M.; Borie, G.; Peirano, P.; Mora, M.D.; Demanet, R. Caracterización de purines para su potencial uso como fertilizante y mejorador de suelos. Agric. Téc. 1995, 55, 251-256.

11. Chambers, B.; Nicholson, N.; Smith, K.; Pain, B.; Cumby, T.; Scotford, I. Managing Livestock Manures: Making Better Use of Livestock Manures on Arable Land; Booklet 1; Ministry of Agriculture: London, UK, 1999; p. 25.

12. Pain, B. Control and utilization of livestock manures. In Grass: Its Production and Utilization, 3rd ed.; Hopkins, A., Ed.; British Grassland Society, Blackwell Science Ltd.: Oxford, UK, 2000; pp. 343-364.

13. De Mendonça Costa, M.S.S.; Cestonaro, T.; de Mendonça Costa, L.A.; Rozatti, M.A.T.; Carneiro, L.J.; Pereira, D.C.; Lorin, H.E.F Improving the nutrient content of sheep bedding compost by adding cattle manure. J. Clean. Prod. 2015, 86, 9-14. [CrossRef] 
14. Bernal, M.P.; Alburquerque, J.A.; Moral, R. Composting of animal manures and chemical criteria for compost maturity assessment. A review. Bioresour. Technol. 2009, 100, 5444-5453. [CrossRef]

15. Archer, M.J. Marketing biosolids: The experience of Milorganite with special reference to Canada. In Proceedings of the Waste Water Biosolids Sustainability: Technical, Managerial, and Public Synergy, Moncton, NB, Canada, 24-27 June 2007; pp. 1017-1019.

16. Mailapalli, D.R.; Thompson, A.M. Polyacrylamide coated Milorganite ${ }^{\mathrm{TM}}$ and gypsum for controlling sediment and phosphorus loads. Agric. Water Manag. 2011, 101, 27-34. [CrossRef]

17. Harrison, E.Z.; Oakes, S.R. Investigation of alleged health incidents associated with land application of sewage sludges. New Solut. 2002, 12, 387-408. [CrossRef]

18. O'Connor, G.A.; Sarkar, D.; Brinton, S.R.; Elliott, H.A.; Martin, F.G. Phytoavailability of biosolids phosphorus. J. Environ. Qual. 2004, 33, 703-712. [CrossRef]

19. Chinualt, S.L.; O'Connor, G.A. Phosphorus release from a biosolids-amended sandy spodosol. J. Environ. Qual. 2008, 37, 937-943. [CrossRef]

20. Ahmad, A.A.; Fares, A.; Abbas, F.; Deenik, J.L. Nutrient concentrations within and below rootzones from applied chicken manure in selected Hawaiian soils. J. Environ. Sci. Health B 2009, 44, 828-843. [CrossRef]

21. Elliott, H.A.; Brandt, R.C.; O'Connor, G.A. Runoff phosphorus losses from surface- applied biosolids. J. Environ. Qual. 2005, 34, 1632-1639. [CrossRef]

22. Gerardeaux, E.; Jordan-Meille, L. Effect of carbon assimilation on dry weight production and partitioning during vegetative growth. Plant Soil 2009, 324, 329-343. [CrossRef]

23. Sparks, D.L. Potassium Dynamics in Soils. In Advances in Soil Science; Stewart, B.A., Ed.; Springer: New York, NY, USA, 1987; Volume 6.

24. Fares, A.; Abbas, F.; Ahmad, A.; Deenik, J.L.; Safeeq, M. Response of selected soil physical and hydrologic properties to manure amendment rates, levels, and types. Soil Sci. 2008, 173, 522-533. [CrossRef]

25. Paramasivam, S.; Richards, K.A.; Alva, A.K.; Richards, A.M.; Sajwan, K.S.; Jayaraman, K.; Heanacho, A.; Afolabi, J. Evaluation of poultry litter amendment to agricultural soils: Leaching losses and partitioning of trace elements in collard greens. Water Air Soil Poll. 2009, 202, 229-243. [CrossRef]

26. Kebrom, T.H.; Douglas, R.; Bandara, S.; Woldesenbet, S.; Carson, L.; Kidane, N. Identification of Phytotoxic Levels of Copper and Nickel in Commercial Organic Soil Amendments Recycled from Poultry Farms and Municipal Wastes. Bull Environ. Contam Toxicol. 2020, 105, 921-926. [CrossRef] [PubMed]

27. Tanha, M. Investigation of Soil Hydro-Structural Parameters Under Various Soil Management Practices and Feasibility of Defining a Soil Quality Indicator: A Case Study. Master's Thesis, Texas A\&M University, College Station, TX, USA, 2019.

28. Bradley, K.; Williams, E.A.; Bailey, D.; Moussavi, M.; Bayabil, H.; El-Hassan, A.; Awal, R.; Fares, A.; Myers, D.; Barouei, J. Organic Amendments Influence the Rhizosphere and Phyllo-sphere Microbiota Profiles of Collard Greens Grown in Southeast Texas. In Proceedings of the International Association for Food Protection (IAFP) Annual Meeting, Louisville, KY, USA, $21-24$ July 2019.

29. Kebrom, T.H.; Woldesenbet, S.; Bayabil, H.K.; Garcia, M.; Gao, M.; Ampim, P.; Awal, R.; Fares, A. Evaluation of phytotoxicity of three organic amendments to collard greens using the seed germination bioassay. Environ. Sci. Pollut. Res. 2019, 26, 5454-5462. [CrossRef] [PubMed]

30. Weyers, S.L.; Archer, D.W.; Johnson, M.F.; Wilts, A.R. Management Drives Differences in Nutrient Dynamics in Conventional and Organic Four-Year Crop Rotation Systems. Agronomy 2020, 10, 764. [CrossRef]

31. Ray, R.L.; Griffin, R.W.; Fares, A.; Elhassan, A.; Awal, R.; Woldesenbet, S.; Risch, E. Soil CO2 emission in response to organic amendments, temperature, and rainfall. Sci. Rep. 2020, 10, 5849. [CrossRef]

32. Ukalska-Jaruga, A.; Siebielec, G.; Siebielec, S.; Pecio, M. The Impact of Exogenous Organic Matter on Wheat Growth and Mineral Nitrogen Availability in Soil. Agronomy 2020, 10, 1314. [CrossRef]

33. Moyo, M.; van Rooyen, A.; Bjornlund, H. The dynamics between irrigation frequency and soil nutrient management: Transitioning smallholder irrigation towards more profitable and sustainable systems in Zimbabwe. Int. J. Water Resour. Dev. 2020, 36 (Suppl. 1), S102-S126. [CrossRef]

34. van Rooyen, A.; Ramshaw, P.; Moyo, M.; Stirzaker, R.; Bjornlund, H. Theory and application of agricultural innovation platforms for improved irrigation scheme management in southern Africa. Int. J. Water Resour. Dev. 2017, 33, 804-823. [CrossRef]

35. Bjornlund, H.; Parry, K.; Pittock, J.; Stirzaker, R.; Van Rooyen, A.F.; Moyo, M.; Mdemu, M.; de Sousa, W.; Cheveia, E.; Munguambe, P.; et al. Transforming Smallholder Irrigation into Profitable and self-Sustaining Systems in Southern Africa. Technical Report. K-water and the International Water Resources Association (IWRA). 2018. Available online: http://oar.icrisat.org/10966/1/ SWM-report-final-web.pdf (accessed on 12 January 2020).

36. Parry, K.; van Rooyen, A.; Bjornlund, H.; Kissoly, L.; Moyo, M.; de Sousa, W. The importance of learning processes in transforming smallholder irrigation schemes. Int. J. Water Resour. Dev. 2020, 36 (Suppl. 1), S199-S223. [CrossRef]

37. van Rooyen, A.; Moyo, M.; Bjornlund, H.; Dube, T.; Parry, K.; Stirzaker, R. Identifying leverage points to transition dysfunctional irrigation schemes towards complex adaptive systems. Int. J. Water Resour. Dev. 2020, 36 (Suppl. 1), S171-S198. [CrossRef]

38. Mahmood, F.; Khan, I.; Ashraf, U.; Shahzad, T.; Hussain, S.; Shahid, M.; Abid, M.; Ullah, S. Effects of organic and inorganic manures on maize and their residual impact on soil physico-chemical properties. J. Soil Sci. Plant Nutr. 2017, 17, 22-32. [CrossRef]

39. Reganold, J.P.; Wachter, J.M. Organic agriculture in the twenty-first century. Nat. Plants 2016, 2, 15221. [CrossRef] [PubMed] 
40. Wortman, S.E.; Holmes, A.A.; Miernicki, E.; Knoche, K.; Pittelkow, C.M. First-season crop yield response to organic soil amendments: A meta-analysis. Agron. J 2017, 109, 1210-1217. [CrossRef]

41. Jain, N.K.; Meena, H.N.; Bhaduri, D. Improvement in Productivity, Water-Use Efficiency, and Soil Nutrient Dynamics of Summer Peanut (Arachishypogaea L.) through Use of Polythene Mulch, Hydrogel, and Nutrient Management. Commun. Soil Sci. Plant Anal. 2017, 48, 549-564. [CrossRef]

42. McCauley, A.; Jones, C.; Jacobsen, J. Soil pH and Organic Matter. Nutr. Manag. Module 2009, 8, 1-12.

43. Basso, B.; Ritchie, J.T. Impact of compost, manure, and inorganic fertilizer on nitrate leaching and yield for a 6-year maize-Alfalfa rotation in Michigan. Agric. Ecosyst. Environ. 2005, 108, 329-341. [CrossRef]

44. Van Es, H.M.; Sogbedji, J.M.; Schindelbeck, R.R. Effect of manure application timing, crop, and soil type on nitrate leaching. J. Environ. Qual. 2006, 35, 670-679. [CrossRef]

45. Eghball, B.; Wienhold, B.J.; Gilley, J.E.; Eigenberg, R.A. Mineralization of manure nutrients. J. Soil Water Conserv. 2002, 57, 470-473.

46. Eghball, B. Nitrogen mineralization from field-applied beef cattle feedlot manure or compost. Soil Sci. Soc. Am. J. 2000, 64, 2024-2030. [CrossRef]

47. Aulakh, M.S.; Khera, T.S.; Doran, J.W. Mineralization and denitrification in upland, nearly saturated and flooded subtropical soil II. Effect of organic manures varying in N content and C: N ratio. Biol. Fert. Soils. 2000, 31, 168-174. [CrossRef]

48. Alleoni, L.R.; Brinton, S.R.; O'Connor, G.A. Runoff and leachate losses of phosphorus in a sandy spodosol amended with biosolids. J. Environ. Qual. 2008, 37, 259-265. [CrossRef]

49. Tinker, P.B. Role of rhizosphere microorganisms in phosphorous uptake by plants. In The Role of Phosphorus in Agriculture; Kwasahneh, F.E., Sample, E.C., Kamprath, E.J., Eds.; American Society of Agronomy: Madison, WI, USA, 1980 ; pp. 617-654.

50. Hayman, D.S. Endomycorrhizas. In Interactions between Non-Pathogenic Micro-Organisms and Plants; Dommergues, Y.R., Krupa, S.V., Eds.; Elsevier: Amsterdam, The Netherlands, 1978; pp. 401-442.

51. Arnold, P.T.; Kapustka, L.A. VA mycorrhizal colonization and spore populations in an abandoned agricultural field after five years of sludge application. Ohio J. Sci. 1987, 87, 112-114.

52. Elrashidi, M.A.; Mays, M.D.; Fares, A.; Seybold, C.A.; Harder, J.L.; Peaslee, S.D.; Van Neste, P. Loss of nitrate-nitrogen by runoff and leaching for agricultural watersheds. Soil Sci. 2005, 170, 969-984. [CrossRef]

53. Leytem, A.B.; Williams, P.; Zuidema, S.; Martinez, A.; Chong, Y.L.; Vincent, A.; Vincent, A.; Cronan, D.; Kliskey, A.; Wulfhorst, J.D.; et al. Cycling Phosphorus and Nitrogen through Cropping Systems in an Intensive Dairy Production Region. Agronomy 2021, 11, 1005. [CrossRef]

54. Alharbi, S.; Majrashi, A.; Ghoneim, A.M.; Ali, E.F.; Modahish, A.S.; Hassan, F.A.S.; Eissa, M.A. A New Method to Recycle Dairy Waste for the Nutrition of Wheat Plants. Agronomy 2021, 11, 840. [CrossRef]

55. Eissa, M.A.; Nasralla, N.N.; Gomah, N.H.; Osman, D.M.; El-Derwy, Y.M. Evaluation of natural fertilizer extracted from expired dairy products as a soil amendment. J. Soil Sci. Plant Nutr. 2018, 18, 694. [CrossRef]

56. Blanco-Canqui, H.; Hergert, G.W.; Nielsen, R.A. Cattle manure application reduces soil compactibility and increases water retention after 71 years. Soil Sci. Soc. Am. J. 2015, 79, 212-223. [CrossRef]

57. Motavalli, P.P.; Kelling, K.A.; Converse, J.C. First-year nutrient availability from injected dairy manure. J. Environ. Qual. 1989, 18, 180-185. [CrossRef]

58. Hepperly, P.; Lotter, D.; Ulsh, C.Z.; Seidel, R.; Reider, C. Compost, manure and synthetic fertilizer influences crop yields, soil properties, nitrate leaching and crop nutrient content. Compos. Sci. Util. 2009, 17, 117-126. [CrossRef]

59. Afzaal, H.; Farooque, A.A.; Abbas, F.; Bishnu, A.; Esau, T. Precision Irrigation Strategies for Sustainable Water Budgeting of Potato Crop in Prince Edward Island. Sustainability 2020, 12, 2419. [CrossRef]

60. Zotarelli, L.; Dukes, M.D.; Scholberg, J.M.S.; Munoz-Carpena, R.; Icerman, J. Tomato nitrogen accumulation and fertilizer use efficiency on a sandy soil, as affected by nitrogen rate and irrigation scheduling. Agric. Water Manag. 2009, 96, 1247-1258. [CrossRef]

61. Kiggundu, N.; Migliaccio, K.W.; Schaffer, B.; Li, Y.; Crane, J.H. Water savings, nutrient leaching, and fruit yield in a young avocado orchard as affected by irrigation and nutrient management. Irrig. Sci. 2012, 30, 275-286. [CrossRef]

62. Alvarenga, P.; Mourinha, C.; Farto, M.; Santos, T.; Palma, P.; Sengo, J.; Morais, M.C.; Cunha-Queda, C. Sewage sludge, compost and other representative organic wastes as agricultural soil amendments: Benefits versus limiting factors. Waste Manag. 2015, 40, 44-52. [CrossRef] [PubMed]

63. Foster, L.G. A Case Study in Toxic Tort Causation: Scientific and Legal Standards Work against Recovery for Vicitms. Envtl. L 1988, 19, 141.

64. Emino, E.R.; Warman, P.R. Biological assay for compost quality. Compos. Sci Util 2004, 12, 342-348. [CrossRef]

65. Barral, M.T.; Paradelo, R. A review on the use of phytotoxicity as a compost quality indicator. Dyn. Soil Dyn. Plant 2011, 5, 36-44.

66. Bolan, N.S.; Szogi, A.A.; Chuasavathi, T.; Seshadri, B.; Rothrock, M.J.; Panneerselvam, P. Uses and management of poultry litter. World Poult. Sci. J. 2010, 66, 673-698. [CrossRef]

67. Yazdankhah, S.; Rudi, K.; Bernhoft, A. Zinc and copper in animal feed-Development of resistance and co-resistance to antimicrobial agents in bacteria of animal origin. Microb. Ecol. Health Dis. 2014, 25, 25862. [CrossRef]

68. Giudice, B.D.; Young, T.M. Mobilization of endocrine-disrupting chemicals and estrogenic activity in simulated rainfall runoff from land-applied biosolids. Environ. Toxicol. Chem. 2011, 30, 2220-2228. [CrossRef] 